\title{
Alopecia with long term use of erlotinib: A case report
}

\section{Uzun süre Erlotinib kullanımı ile gelișen Alopesi: Bir olgu sunumu}

\author{
Erdem Sen, İrem Öner, Özlem Ata \\ Selçuk Üniversitesi Tıp Fakültesi, Tıbbi Onkoloji Bilimdalı, Konya
}

Dergiye Ulaşma Tarihi: 01.11.2017 Dergiye Kabul Tarihi: 22.12.2017 Doi: 10.5505/aot.2018.97658

\section{ÖZET}

Akciğer kanseri dünya genelinde erkek ve kadınlarda ikinci sıklıkta görülen, her iki cinsiyette en sık ölüme yol açan kanser türüdür. Epidermal büyüme faktörü reseptörü (EGFR) hücre dışında ligand bağlanma ve hücre içi tirozin kinaz bölümleri olan transmembran glikoproteinlerdir. Erlotinib, Gefitinib, Afatinib, Lapatinib gibi ajanlar EGFR'nin hücre içi tirozin kinaz bölümü aktivasyonunu inhibe etmektedir. Bu ajanlar genellikle iyi tolere edilirler. Tedavi sırasında cilt toksisitesi olarak en sık cilt düküntüsü görülmektedir. Erlotinib tedavisi ile ilişkili alopesi görülebilen bir durumdur. İleri yaş, bayan hastalarda uzun süreli tedavi ile karşımıza çıkabilir. Skatrisyel ve skatrisyel olmayan alopesi şeklinde görülebilmektedir. Biz bu çalışmamızda erlotinib kullanımı ile ilişkili alopesi gelişen olgumuzu sunduk.

Anahtar Kelimeler: Erlotinib, Alopesi, EGFR

\begin{abstract}
Lung cancer is the second most common cancer type in men and women worldwide, and the most frequent type of cancer that causes death in both sexes. Epidermal growth factor receptor (EGFR) is a transmembrane glycoprotein that has extracellular ligand binding and intracellular tyrosine kinase segments. Agents such as Erlotinib, Gefitinib, Afatinib, Lapatinib inhibit the activation of the intracellular tyrosine kinase domain of EGFR. These agents are usually well tolerated. Skin rash is the most common skin toxicity during treatment. Alopecia related to erlotinib therapy is a condition that can be seen.. Elderly and female patients may be confronted with long-term treatment. It can be seen as a cicatricial and non-cicatricial alopecia. In this study, we tried to present our case that developing alopecia related to the use of erlotinib.
\end{abstract}

Keywords: Erlotinib, Alopecia, EGFR

\section{GíRiş}

Akciğer kanseri dünya genelinde erkek ve kadınlarda ikinci sıklıkta görülen, her iki cinsiyette en sık ölüme yol açan kanser türüdür. Akciğer kanserinin yaklaşı olarak \% 85'ini küçük hücreli dış1 akciğer kanseri (KHDAK) oluşturmaktadır (1). Tanı genellikle ileri evrede konulmaktadır.

Epidermal büyüme faktörü reseptörü (EGFR) hücre dışında ligand bağlanma parçası ve hücre içi tirozin kinaz parçası olan transmembran glikoproteinlerdir. EGFR KHDAK, baş boyun, böbrek, meme, pankreas, kolon kanserlerinde tümör hücrelerince eksprese edilmektedir. EGFR ailesi yapisal olarak benzer 4 reseptör tirozin kinaz proteininden oluşmaktadır: ErbB-1 (EGFR), ErbB-2 (HER-2), ErbB-3 (HER-3), ErbB-4 (HER-4) (2). EGFR tümör büyümesinde ve progresyonunda önemli rol oynamaktadır. KHDAK'de EGFR \%40- 80 oranında eksprese edilmektedir (3).

EGFR sinyal iletimi hücre dișı bölüme ligand bağlanması önlenerek (monoklonal antikorlar yolu ile) veya hücre içi tirozin kinaz bölümü inhibe edilerek (tirozin kinaz inhibitörleri (TKI) ile) baskılanmaya çalışılmaktadır. Erlotinib, Gefitinib, Afatinib, Lapatinib gibi ajanlar ile EGFR'nin hücre içi tirozin kinaz bölümü aktivasyonu inhibe edilmektedir. EGFR inhibitörleri genellikle iyi tolere edilir. EGFR'lerin epidermis, k1l 
folikülü ve sebase bezlerde yoğun eksprese edilmesi nedeniyle, EGFR inhibitorleri ile tedavi edilen olgularda en sik gözlenilen yan etki dermatolojik yan etkilerdir. Özellikle akneiform erupsiyonlar, deri kuruluğu, eritematöz ve egzematize lezyonlar, tırnak değişiklikleri, kıllarda ve saçlarda değişiklikler gözlenmektedir(4).

Biz bu çalışmamızda erlotinib kullanımı ile ilişkili alopesi gelişen olgumuzu sunduk.

\section{OLGU SUNUMU}

5 y1l öncesinde yüzeyel mesane malign neoplazmı tanısı olan hastanın kontrol amaçlı çekilen toraks BT tetkikinde sağ akciğer parankiminde çok sayıda en büyüğü $1.5 \mathrm{~cm}$ 'lik nodüller saptandi. Yapılan biyopsi sonucunda KHDAK (adenokarsinom) tanis1 konuldu. Evreleme tetkiklerinde paryetal plevrada metastaz ile uyumlu nodüler lezyonlar saptand. Yapılan biyopsi akciğer adenokarsinomu metastazı olarak rapor edildi. Evre 4 kabul edilen hastaya ilk sira kemoterapi tedavisi verildi. 3. Kür sonunda yanit değerlendirilmesinde stabil yanıt elde edildi. EGFR mutasyon analizi istendi. Tetkik sonucunda exon 19'da delesyon saptandi. Hastanın EGFR'de driver mutasyonu olması, 3 kür kemoterapi sonucunda stabil yanıt elde edilmesi nedenleri ile erlotinib tedavisine (150 $\mathrm{mg}$ /gün) geçildi. Kemoterapi tedavisi ile alopesi gelişen hastanın kemoterapi tedavisinin kesilmesinden 2 ay sonra, erlotinib tedavisi altında iken alopesisi düzeldi. Hastada anti EGFR tedavisinde tipik olarak gözlenen akneiform erupsiyonlar görülmedi. Sonraki takiplerinde stabil hastalık bulguları olması, tedavi kesilmesini gerektirecek toksisite de olmamas1 nedeni ile tedaviye devam edildi. Erlotinib tedavisinin 18 . ayında ise kontrollerde hastada scalpte grade 2 üzeri eritemli, yer yer krutlu alopesi gelişti (Resim 1). Hasta dermatoloji bölümü ile konsülte edildi. Hastadan scalpten alınan örneklerde mikolojik veya bakteriyolojik etken saptanmadi. Hormonal, vitamin ve mineral tetkikleri normal saptandi. Alopesi yapabilecek ek bir ilaç kullanımı yoktu. Trikotillomani veya travma öyküsü yoktu. Hasta scalpten biyopsi yapılmasını kabul etmedi. Topikal steroid, antihistaminik, oral antibiyotik tedavileri verildi. Erlotinib tedavisine de ara verildi. Lezyonları lokal olarak gerileyen hastaya erlotinib tedavisi tekrar başland. Takiplerinde alopesi düzelmedi. Hastada halen stabil hastalık bulguları mevcut. Tedavisi halen devam ediyor. Hastamız yaklaşık olarak 3 yıldır erlotinib tedavisi alıyor. Tedavisi devam ederken ara ara scalpte grade1-2 üzeri krutlu, eritemli cilt lezyonları gelişiyor. Topikal tedaviler ve ilaca ara verilmesi ile lezyonları geriliyor.

\section{TARTIŞMA}

EGFR cilt dokusunda epidermal büyümede, ultraviyolenin neden olduğu hasara karşı korunmada, inflamasyonun baskilanmasında, yara iyileşmesinde, yapısal bütünlüğün ve homeostazın sağlanmasında önemli görevleri bulunmaktadir (5). EGFR en siklıkla epidermisin bazal ve suprabazal tabakalarında ve k1l folikülü k1lıfinda prolifere olan keratinositlerde eksprese edilir (6). EGFR inhibisyonu keratinosit çoğalmasının, farklılaşmasının, migrasyonunun bozulmasına ve keratinositlerin birbirleriyle olan bağlantılarında değişikliğe neden olur (7). EGFR saç folliküllerinde gelişen inflamasyonun rezolüsyonunda önemli rol almaktadır. Saç follikülünde EGFR inhibitörü tedavisi ile ilişkili gelişen destrüksiyonun, inflamatuar infiltrasyonun patogenezinde bu mekanizmanın rol aldığı düşünülmektedir (8). Anti EGFR tedavisinin saç gelişiminde anagen fazına etki ederek toksisite oluşturduğu gösterilmiştir (9).

EGFR TKI tedavisi sirasında cilt toksisitesi sık karşımıza çıkan klinik bir durumdur. En s1k görülen cilt toksisitesi deri döküntüleridir (10). EGFR TKİ tedavisi ile ilişkili saç toksisiteleri de görülebilmektedir. Siklıkla scalpte kıvırcık, daha ince ve kırılgan saçlar görülmektedir. Ayrıca kaş ve kirpiklerde kıvrılma ve trikomegali, yüzde hipertrikoz görülebilmektedir. Bu değişikliklerin görülme zamanı farklılık göstermektedir. EGFR inhibitörü tedavisi başlangıcından 7-10 hafta ile aylar sonrasında görülebilmektedir (11). Bizim vakamızda EGFR TKI ile ilişkili belirgin bir cilt toksisitesi gelişmeden, kemoterapi tedavisi kesilmesi sonrasinda alopesisi düzelen hastada erlotinib tedavisinin 18. Ayında tekrar alopesi meydana geldi. 
Alopesi genellikle skatrisyel ve skatrisyel olmayan tip olarak sinıflandirılmaktadır. Skatrisyel alopesi scalpin inflamasyonu, kalıc1 saç kaybı ile karakterizedir. Skatrisyel olmayan alopeside ise saç follüküllerinde inflamasyon, destrüksiyon beklenen bir bulgu değildir. Bizim olgumuzda takiplerinde alopesi daha öncesinde kemoterapi tedavisi sonrasinda olduğu gibi düzelmedi. Hastaya biyopsi yapılamadı bu nedenle saç folliküllerinde inflamatuar infiltrasyon, fibrosis bulgusu gösterilemedi.

EGFR hedefli tedaviler ile ilișkili cilt toksisitesi (rash,akneiform erupsiyon) gelişen hastaların ortalama sağkalımları, gelişmeyenlere göre daha uzun olduğu gösterilmiştir(5). Alopesi gelişen hastalarda sağkalım farkı ile ilgili yeterli veri bulunmamaktadır. Literatür incelendiğinde EGFR TKİ tedavileri ile ilişkili hem skatrisyel, hemde skatrisyel olmayan alopesi olguları rapor edilmiştir. Olgular incelendiğinde hastaların yaşlı ve bayan cinsiyet olduğu, genellikle akciğer kanseri nedeni ile tedavi aldıkları görülmektedir. Olgularda genellikle enfeksiyöz neden saptanmadığı bildirilmiştir. Tedavi ve alopesi gelişme süresi bakımından incelendiğinde olgularda alopesi tedavi başlangıcından 2 hafta ile 3 yıl sonrasında görüldüğü bildirilmiştir (12-16). Bizim olgumuzdaki özellikler literatür verileri ile uyumlu idi. Enfeksiyöz neden gösterilememesine rağmen oral antibiyotik tedavisi sürece katkı sağlamıştır.

Erlotinib EGFR'yi hedefleyen TKI bir ilaçtır. Sürücü mutasyonu olan KHDAK olgularında tedavide sık kullandığımız bir ajandır. Cilt toksisiteleri bu tedavinin önemli yan etkileridir. Erlotinib tedavisi ile ilişkili alopesi nadir görülen bir toksisitedir. Patogenezi tam olarak bilinmemektedir. Alopesi EGFR'yi hedefleyen TKİ tedavisi alan olgularda göz önünde bulundurulması gereken bir toksisitedir.

\section{Conflict of interest: None}
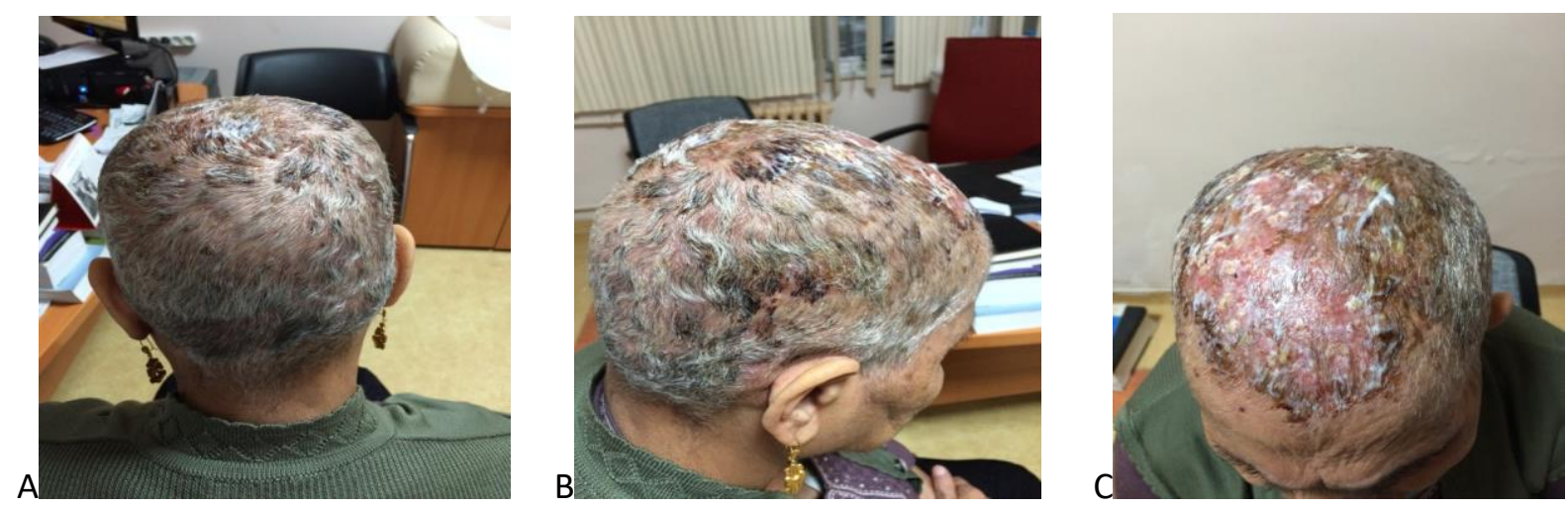

Resim 1: A,B,C: Erlotinib tedavisinin 18. Ayında gelişen scalpte eritemli, krutlu, skatrisyel alopesi alanları görülmektedir. Hastaya topikal tedavi amaçlı steroid içeren krem verilmiştir. Resimler topikal tedavi sonrasında çekilmiştir. Lezyonlar normalde akıntılı değildir. 


\section{REFERANSLAR}

1. Siegel R, Ward E, Brawley O, Jemal A. Cancer Statistics 2011, The Impact of Eliminating Socioeconomic and Racial Disparities on Premature Cancer Deaths. CA Cancer J Clin 2011; 61(4): 212-236.

2. Mendelsohn J, Baselga J. Status of epidermal growth factor receptor antagonists in the biology and treatment of cancer. J Clin Oncol 2003; 21(14): 2787-2799.

3. Scagliotti GV, Selvaggi G, Novello S, Hirsch FR. The biology of epidermal growth factor receptor in lung cancer. Clin Cancer Res. 2004; 10 (12): 4227-4232.

4. Cowen EW. Epidermal growth factor receptor inhibitors: A new era of drug reactions in a new era of cancer therapy. J Am Acad Dermatol 2007;56:514-7.

5. Lynch TJ, Kim ES, Eaby B, et al. Epidermal growth factor receptor inhibitor-associated cutaneous toxicities: An evolving paradigm in clinical management. The Oncologist 2007;12 (5):610-21.

6. Li T, Perez-Soler R. Skin toxicities associated with epidermal growth factor receptor inhibitors. Targ Oncol 2009;4 (2):107-19.

7. Tsimboukis S, Merikas I, Karapanagiotou EM, et al. Erlotinib-induced skin rash in patients with non-smallcell lung cancer: pathogenesis, clinical significance, and management. Clin Lung Cancer 2009;10 (2):106-11.

8. Heck DE, Laskin DL, Gardner CR, Laskin JD. Epidermal growth factor suppresses nitric oxide and hydrogen peroxide production by keratinocytes: potential role for nitric oxide in the regulation of wound healing. $\mathrm{J}$ Biol Chem 1992; 267:21277-80.

9. Mak KK, Chan SY: Epidermal growth factor as a biologic switch in hair growth cycle. J Biol Chem 2003; 278 (28): 26120-26126.

10. Robert C, Soria JC, Spatz A, et al Cutaneous sideeffects of kinase inhibitors and blocking antibodies. Lancet Oncol 2005;6 (7):491-500.

11. Agero AL, Dusza SW, Benvenuto-Andrade Busam KJ, Myskowski P, Halpern AC. Dermatologic side effects associated with the epidermal growth factor receptor inhibitors. J Am Acad Dermatol 2006;55 (4):657-670.

12. Pongpudpunth M, Demierre MF, Goldberg LJ: A case report of inflammatory nonscarring alopecia associated with the epidermal growth factor receptor inhibitor erlotinib. J Cutan Pathol 2009; 36 (12): 1303-1307.

13. Donovan JC, Ghazarian DM, Shaw JC: Scarring alopecia associated with use of the epidermal growth factor receptor inhibitor gefitinib. Arch Dermatol 2008; 144 (11): 1524-1525

14. Costa DB, Kobayashi S, Schumer ST: Erlotinibassociated alopecia in a lung cancer patient. $\mathbf{J}$ Thorac Oncol 2007; 2 (12): 1136-1138.

15. Graves JE, Jones BF, Lind AC, Heffernan MP: Nonscarring inflammatory alopecia associated with the epidermal growth factor receptor inhibitor gefitinib. J Am Acad Dermatol 2006; 55(2): 349-353. 